\title{
Adder Bite in the British Army 1979-1988: A Decade of Experience
}

\author{
Major A Hawley \\ $M B, C h B, R A M C$ \\ Specialist in Occupational Medicine \\ 23 Parachute Field Ambulance, Rhine Barracks, Aldershot GU12 2 AS
}

\begin{abstract}
SUMMARY: The results of hospital admissions for adder bite suffered by British Army personnel were reviewed over a ten year period. They confirmed the low bite rate and the risk factors previously demonstrated in earlier studies. In particular, the dangers of handling and attempting to catch the snake were highlighted. Also illustrated was a general ill-preparedness by clinicians to manage the condition. In this connection, the use of specific Zagreb anti-venom preparation for cases of severe poisoning is advocated, as is admission to hospital for assessment and appropriate monitoring. Adder bite is both unusual and unpredictable so caution needs to be exercised in the initial clinical appraisal.
\end{abstract}

\section{Introduction}

Of the three indigenous snakes in Britain only one is venomous. The adder, Vipera berus, possesses venom which it usually employs to subdue its prey ${ }^{1}$. Its diet normally consists of small mammals, lizards, frogs and birds. These animals are killed by the effects of the venom which are generally described as being haemotoxic, cytotoxic and vasculotoxic ${ }^{2}$. These are characteristics shared by many other venoms of the Viperidae ${ }^{3}$.

The adder is a snake which rarely grows larger than 60 $\mathrm{cms}$. It may be distinguished by dark zig-zag markings along its back although they may be obscured if the background colour of the snake is itself dark. Thus, some individuals may be dark red or black. More usually, they are grey or brown. One feature, however, which tends to be constant is the prominent $V$ shaped marking at the back of the head ${ }^{4}$. This may help identify the snake although the only reliable method is to examine the scale type and pattern. The adder's eye is elliptical with a typical viperid vertical slit, as opposed to the round eye shapes of the grass and smooth snakes ${ }^{1}$.

Vipera berus is a wide ranging snake which is found throughout the United Kingdom and European continent from Northern Spain and Italy up to the northern regions of Scandinavia. In its more southerly habitats it overlaps with the northerly distribution of some other viperid snakes namely the aspic viper, Vipera aspis, the meadow viper, Vipera corsinii, and the sand viper, Vipera ammodytes ${ }^{4}$. The adder may be distinguished from the others by virtue of the inverted $V$ shape at the back of its head and its preferred habitat. The snake prefers dry, sandy heathland and forest edges. Nevertheless, occasionally it may be found in wetter places. This is especially true when the weather is hot. At such times the reptile may withdraw to areas offering dampness and shelter ${ }^{5}$.

The adder exhibits marked seasonal variations in its habits. It goes into hibernation when the autumn temperatures begin to fall. This hibernation will last until spring, usually March, and the snake will resume feeding ${ }^{5}$. Mating takes place in April or May and the young are born in the summer. These timings are approximate but are significant since they are clues to the activity levels of the snake. Thus, when emerging from hibernation the reptile will be sluggish but will possess a full load of venom ${ }^{5}$. During the mating season the snake is likely to be maximally active with a gradual slowing down during late summer. This pattern of activity is of importance in its effect upon human activities.

In common with nearly all snakes, the adder will make 0 an attempt to avoid human contact ${ }^{7}$. However, ifo cornered or surprised the snake will attack. Its defensive posture is one of a loud hissing followed by a strike ${ }^{8}$. Notwithstanding this, many encounters with the adder are inadvertent. Equally, a proportion of adder bites are sustained whilst actually handling the snake ${ }^{5}$.

\section{Method}

This study is a retrospective survey of the reported cases held in the MEDSTATS programme. Clinical details were confirmed by reference to the hospital notes and results.

\section{Results}

Fig 1 gives the aggregate results of this series. There was a total of 13 patients admitted to hospitals after having sustained an adder bite. Clearly, the total only refers to actual documented hospital admissions. No data were available on those individuals who were bitten and did not warrant hospital admission. The figures refer to both civilian and military hospitals.

All the 13 cases were of male soldiers and only 2 of these were bitten accidentally; the rest were injured as a consequence of actually handling or trying to capture the snake. This is reflected in the site of bite, with 10 patients having suffered bites of the hands. Indeed, only one case in this series represents an attack on a part other than the upper limb; this was a bite on the right ankle.

The commonest month for adder bite was May with 5 bites out of a total of 13. June was the next most frequent with 4 bites, then July with 2 and March and September one each. Similarly, the location of the patient when bitten shows a gradation, with the commonest one being 


\begin{tabular}{|c|c|c|c|c|c|c|c|c|c|c|}
\hline $\begin{array}{l}\text { PATIENT } \\
\text { DETAILS }\end{array}$ & $\begin{array}{l}\text { SITE OF } \\
\text { BITE }\end{array}$ & LOCATION & $\begin{array}{l}\text { TIME OF } \\
\text { YEAR } \\
\text { (D) }\end{array}$ & $\begin{array}{l}\text { PATIENT } \\
\text { ACTIVITY } \\
\text { AT TIME } \\
\text { OF BITE } \\
\text { (E) }\end{array}$ & $\begin{array}{l}\text { LENGTH OF } \\
\text { HOSPITALI- } \\
\text { SATION } \\
\text { (F) }\end{array}$ & SYMPTOMS & $\begin{array}{l}\text { INVESTIGATIONS } \\
\text { PERFORMED } \\
\text { (H) }\end{array}$ & $\begin{array}{l}\text { ABNGMAL } \\
\text { RESUETS } \\
\vec{\omega} \\
\text { (I) } \overbrace{1}^{1}\end{array}$ & $\begin{array}{l}\text { TREATMENT } \\
\text { GIVEN }\end{array}$ & $\begin{array}{l}\text { TIME TO } \\
\text { COMPLETE } \\
\text { RECOVERY } \\
\text { (K) } \\
\end{array}$ \\
\hline 16 yrs M & $\mathrm{R}$ thumb & Northumbria & May & handling snake & 2 days & local swelling & $\begin{array}{l}\text { Fbc } \\
\mathrm{U}+\mathrm{E} \\
\text { CXR }\end{array}$ & nil $\begin{array}{r}\frac{1}{N} \\
0\end{array}$ & antibiotics & 7 days \\
\hline 22 yrs M & $\begin{array}{l}\text { Rindex } \\
\text { finger }\end{array}$ & Surrey & June & handling snake & 4 days & $\begin{array}{l}\text { local and } \\
\text { regional } \\
\text { swelling, } \\
\text { nausea }\end{array}$ & $\begin{array}{l}\text { Fbc } \\
\text { U+E } \\
\text { ECG }\end{array}$ & 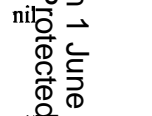 & Piriton & 15 days \\
\hline 18 yrs M & $\mathrm{L}$ forearm & Gloucestershire & July & $\begin{array}{l}\text { trying to } \\
\text { catch snake }\end{array}$ & 4 days & $\begin{array}{l}\text { local } \\
\text { swelling }\end{array}$ & $\begin{array}{l}\text { Fbc } \\
\mathrm{U}+\mathrm{E} \\
\mathrm{ECG}\end{array}$ & 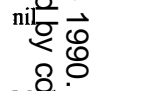 & nil & 10 days \\
\hline 26 yrs M & $\mathrm{R}$ forearm & Hampshire & May & $\begin{array}{l}\text { accidentally } \\
\text { disturbed } \\
\text { snake }\end{array}$ & 10 days & $\begin{array}{l}\text { local and } \\
\text { regional } \\
\text { swelling, } \\
\text { vomiting, } \\
\text { nausea, } \\
\text { hypotension }\end{array}$ & $\begin{array}{l}\text { Fbc } \\
\text { U+E } \\
\text { CXR } \\
\text { ECG } \\
\text { Clotting studies }\end{array}$ & 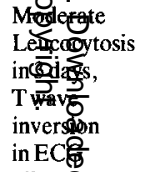 & $\begin{array}{l}\text { N/saline } \\
\text { drip, } \\
\text { intravenous } \\
\text { hydrocortisone, } \\
\text { antibiotics }\end{array}$ & 29 days \\
\hline 19 yrs M & R hand & Wiltshire & May & handling snake & 1 days & nil & nil & nil $\varrho$ & nil & 1 day \\
\hline 23 yrs M & L hand & Surrey & June & handling snake & 8 days & $\begin{array}{l}\text { local and } \\
\text { regional } \\
\text { swelling, } \\
\text { nausea, } \\
\text { vomiting }\end{array}$ & $\begin{array}{l}\text { Fbc } \\
\text { U+E } \\
\text { CXR } \\
\text { ECG } \\
\text { Clotting studies }\end{array}$ & 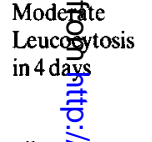 & $\begin{array}{l}\text { antibiotics, } \\
\text { intravenous } \\
\text { hydrocortisone }\end{array}$ & 21 days \\
\hline 25 yrs $M$ & L thumb & $\begin{array}{l}\text { Hohne, } \\
\text { West Germany }\end{array}$ & March & handling snake & 3 days & local & nil & nil 层 & antibiotics & 3 days \\
\hline 22 yrs $\mathrm{M}$ & $\begin{array}{l}\text { R middle } \\
\text { finger }\end{array}$ & Hampshire & September & handing snake & 5 days & $\begin{array}{l}\text { local and } \\
\text { regional } \\
\text { swelling, } \\
\text { hypotension, } \\
\text { vomiting }\end{array}$ & $\begin{array}{l}\text { Fbc } \\
\text { U+E } \\
\text { CXR } \\
\text { ECG } \\
\text { Clotting studies }\end{array}$ & $\begin{array}{l}\text { Twave } \\
\text { invers } \\
\text { in EC }\end{array}$ & $\begin{array}{l}\text { intravenous } \\
\text { hydrocortisone, } \\
\text { antibiotics }\end{array}$ & 17 days \\
\hline $28 \mathrm{yrs} \mathrm{M}$ & $\begin{array}{l}\text { Lindex } \\
\text { finger }\end{array}$ & $\begin{array}{l}\text { Herford, } \\
\text { West Germany }\end{array}$ & June & handlingsnake & 7 days & $\begin{array}{l}\text { local } \\
\text { swelling, } \\
\text { necrosis } \\
\text { later over } \\
\text { bite area }\end{array}$ & $\begin{array}{l}\text { Fbc } \\
\text { U+E } \\
\text { CXR } \\
\text { ECG } \\
\text { Clotting studies }\end{array}$ & 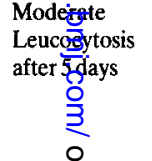 & $\begin{array}{l}\text { intravenous } \\
\text { hydrocortisone, } \\
\text { antibiotics, } \\
\text { later surgical } \\
\text { debridement } \\
\text { and skin graft }\end{array}$ & 82 days \\
\hline 35 yrs $M$ & $\begin{array}{l}\text { Rindex } \\
\text { finger }\end{array}$ & Surrey & May & $\begin{array}{l}\text { trying to } \\
\text { catch snake }\end{array}$ & 3 days & $\begin{array}{l}\text { local } \\
\text { swelling }\end{array}$ & $\begin{array}{l}\text { Fbc } \\
\mathrm{U}+\mathrm{E}\end{array}$ & nil $\frac{5}{2}$ & antibiotics & 8 days \\
\hline $22 \mathrm{yrs} M$ & $\begin{array}{l}R \text { index } \\
\text { finger }\end{array}$ & Hampshire & May & handling snake & 2 days & $\begin{array}{l}\text { local } \\
\text { swelling }\end{array}$ & $\begin{array}{l}\text { Fbc } \\
\mathrm{U}+\mathrm{E}\end{array}$ & nil & nil & 2 days \\
\hline 21 yrs M & R ankle & Wales & July & $\begin{array}{l}\text { accidentally } \\
\text { disturbed snake }\end{array}$ & 2 days & $\begin{array}{l}\text { local } \\
\text { swelling }\end{array}$ & $\mathrm{Fbc}$ & nil & nil & 4 days \\
\hline $20 \mathrm{yrs} M$ & $\begin{array}{l}\text { R middle } \\
\text { finger }\end{array}$ & Yorkshire & June & handling snake & 1 day & nil & $\begin{array}{l}\text { Fbc } \\
U+E\end{array}$ & nil & nil & 1 day \\
\hline
\end{tabular}


the South East of England. Interestingly the total included 2 soldiers bitten whilst serving in Germany. The symptomatology showed the almost universal feature of local swelling. This is defined as a swelling of the afflicted structure and its immediate surroundings. For instance, local swelling of a bite to the thumb would include the thumb ball and the hand. Regional swelling would involve the whole of the upper limb.

In 3 cases significant nausea followed by vomiting was suffered. In 2 of these cases there was at least one episode of hypotension as well. Also of interest is the single case of necrosis over the actual area of snake bite. This is an unusual finding. Other abnormal results included 3 cases of moderate leucocytosis within 3 days of the bite. This was taken as a rise in white blood cell count of up to $17.3 \times 10^{9}$ per litre in the worst case. Similarly, there were 2 cases of $T$ wave inversion in the ECG. Treatments given seemed to include mainly antibiotics, in 7 cases, and intravenous hydrocortisone, 4 cases. No treatment at all, other than reassurance, was offered in 5 cases. Specific anti-venom was not given at all in this series.

The recovery time to complete return to normal duties varied enormously. The average period of recovery was 15.38 days. However, if the complicated case of skin grafting onto the necrotic area is omitted, the average recovery time falls to 9.08 days. No cases of death or permanent disability were recorded in this series.

\section{Discussion}

Adder bite is a relatively unusual condition in England and Wales. It is naturally enough the result of adder incidence and human activity. In this context snakebite is a function of the interplay between snakes and human activities. This is a finding supported by Reid's work in Malaya ${ }^{9}$. Thus, the heathlands of southern England are particularly productive of adder bite given the relatively large populations of both adders and humans. Fig 2 gives the monthly bite rate. A striking feature is the absence of bites in August. This reflects the leave period of most army units and hence a decrease in the likelihood of soldier - adder interactions. Bites continue to be suffered by civilians as demonstrated in other studies. Within the United Kingdom, specifically the Aldershot area, Hawley described an average annual bite rate requiring hospitalisation of 3 per year ${ }^{7}$. Death from adder bite is fortunately rare. This series supports that finding. Between 1950 and 1972 in England and Wales, there was one reported death from adder envenomation but 61 from bee and wasp sting ${ }^{5}$. Similarly, long term disability from the venom is also uncommon. The one case which took 82 days to fully recover in this series, was subject to surgical intervention. It was the requirement to protect the skin graft that led to this long delay. Yet even including this long case, the average duration of recovery was 15.38 days.

Vipera berus venom is a complex mixture of proteases whose combined effects are fundamentally cytotoxic and haemotoxic ${ }^{3}$. The poison is produced and stored in sacs which lie postero-inferior to the eye orbit. The venom is delivered to the victim by inserting the fangs into its tissues and pumping the straw coloured poison into the wound via the hollow tube of the fang ${ }^{6}$. The whole apparatus functions rather like a hypodermic syringe. Once delivered the venom acts by a variety of different mechanisms. The cytotoxic element seems to have an effect on vascular endothelial linings. This helps to explain the swelling seen in cases of envenomation. Indeed, early and massive oedema is a reliable indication of poisoning, swelling beginning as soon as 5 minutes after a bite has been described ${ }^{7}$. In any case, if no swelling has been seen 6 hours after a bite it is unlikely that significant envenomation has occurred ${ }^{5,10}$. After 24 hours the swelling becomes overtly haemorrhagic. Again the damaged endothelial structure would explain this phenomenon. Another component of adder venom is an haemotoxic element ${ }^{12}$. This certainly seems to be the mechanism of action in the preferred prey species. Nevertheless, in this series no evidence of coagulation abnormality was found. Similar findings have been described in other viperid envenomations ${ }^{3}$. The explanation may lie in the complexities of dose related responses. Adder venom has a much lower potency than many other viper poisons and is also delivered in small doses. Thus, in a large animal as represented by man, the small amount of venom may be insufficient to produce the systemic haemotoxic effects.

Another important element in adder venom is a direct 8 cardiotoxic factor. This has not yet been isolated in adders but there is good evidence for its existence. Two cases in this series showed $T$ wave inversion after envenomation. This relatively non-specific sign has been observed by others ${ }^{3,11}$. An unusually severe cardiac complication was reported by Brown and Dewar ${ }^{13}$. They described a case of a 22 year old man who suffered myocardial damage, probably infarction, after an adder bite. A different problem of second degree heart block

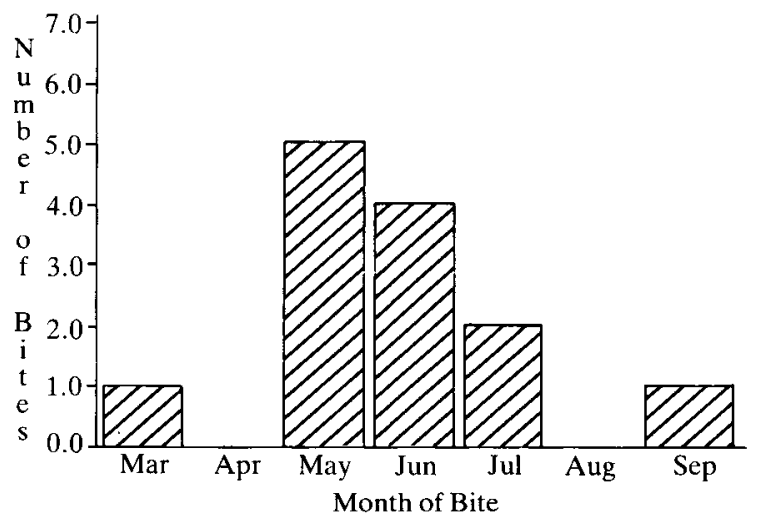

Fig 2 Monthly Bite Rate 
in a patient with a pre-existing history of ischaemic heart disease was described by Moore ${ }^{14}$. These more serious cardiac episodes are very much the exception to the general rule. The commonest manifestation of heart involvement in adder envenomation is T wave inversion. Confusingly, there seems to be little correlation between its presence and the severity of poisoning. Even mild cases of envenomation may show this trace ${ }^{5}$.

A much more sensitive indicator of severity of bite is white blood cell count. A moderate leucocytosis, specifically neutrophil, of between 16 and $26 \times 10^{9} / 1$ was found in 3 cases in this series. These correspond to the most severely envenomed cases. Similar findings have been found elsewhere ${ }^{3,5,7}$. Onset of leucocytosis may be as early as 2 hours after the bite but 24 to 36 hours seems more general. Certainly, any patient with early onset of swelling and neutrophil leucocytosis following adder bite must be assumed to have suffered significant and possibly severe envenomation. This is not to say that all adder bites lead to poisoning. Approximately $70 \%$ of viper bites actually cause envenomation ${ }^{9}$. Many factors affect whether a victim is poisoned or not. Amongst them are the time of year since emergence from hibernation is a period of maximal venom holdings. Similarly, time since last use of venom will also be of significance by virtue of venom store depletion ${ }^{15}$. Additionally, it seems that in many defensive bites, at least initially, the intention by the snake is to frighten and warn off rather than to envenom ${ }^{6}$. Clinical features of envenomation may well be confused in the early stages by the features of a fright response. The actual experience of suffering a snake bite is both physically painful and psychologically alarming. Nearly all patients exhibit some evidence of alarm and anxiety. These may cloud the rest of the clinical picture ${ }^{7}$.

Significantly in this series the commonest time for bites was May and June, with 9 incidents occurring in these 2 months. This is earlier than in other series ${ }^{5}$. However, in other respects this series confirmed others' experiences. Thus, all those bitten were male. A study in Sweden also found that men were more likely than women to suffer bites ${ }^{16}$. Other studies have also found this to be true $e^{5,9}$. It seems that men are more likely to handle the reptiles. Interestingly, all but 2 of this army series were bites sustained whilst either trying to capture or physically handle the snake.

Having been admitted to hospital a variety of different treatments were given. The use of antibiotics was common, presumably on the basis that any bite was likely to be dirty and therefore infection a distinct possibility. Whilst this remains a theoretical risk there is no evidence that adder bite is an infective hazard. Nevertheless, antibiotic cover seems a prudent council. Anti-tetanus measures also seem to be advisable if existing cover has lapsed. Also of interest was that in 4 cases hydrocortisone was administered. Again, this was on presumptive grounds against toxic shock developing. The 4 patients who received the steroid were the most seriously envenomed cases. Of real interest and indeed concern, was the omission of specific anti-venom from treatment regimes even of the most seriously poisoned $\underset{\mathbb{Q}}{\vec{\alpha}}$ patients. This may reflect the widespread confusion $\stackrel{1}{2}$ between the old Pasteur type anti-venom, which had $\bigcirc$ real risks of anaphylactic reactions, and the more recent much safer Zagreb preparation ${ }^{18}$. Earlier uses of Pasteur $\stackrel{\oplus}{.}$ solutions did indeed cause fatalities ${ }^{17}$. However, the $\overrightarrow{\vec{F}}$ definitive treatment for severe envenomation is Zagrebanti-venom ${ }^{18}$. This may be used even relatively late in the treatment; up to 4 days after the bite has been $\frac{\bar{\sigma}}{\bar{c}}$ advocated ${ }^{9}$.

In the past some authorities have recommended $\cong$ killing the snake to aid in identification ${ }^{19}$. This advice seems to be misguided since in the United Kingdom and $\vec{O}$ Northern Europe, the adder is the only venomous snake $\overrightarrow{ }$ hence identification is not a real problem. The situation $\vec{\omega}$ may well be different in the areas of the adder's distribution where other vipers are found. Even so, 3 extreme care needs to be taken against further bites. It is ? worth noting that delayed head reactions have been $\vec{\omega}$ described. In these, victims have been envenomed by a decapitated adder head up to 20 minutes after severance 5 .

Another piece of advice given, especially by을 American workers, is the incision and sucking of the sige $\rightarrow$ of the bite ${ }^{20}$. There is no evidence that this is of benefip. $c$ Indeed, there are real dangers in this approach $\frac{1}{8}$ Experience with adder bite suggests that this practice 15 at best ineffective and at worst positively harmful ${ }^{21}$.

Generally, there is no place in the acute stages for. surgical intervention. The temptation exists to intervene when faced by the massive swelling of a severe envenomation. In such a clinical picture the pulses are often impalpable and so the question of surgical $\stackrel{\varrho}{\circ}$ decompression may arise. Warrell advises against early $\stackrel{\unrhd}{\complement}$ surgical intervention and counsels objective assessment $\overrightarrow{\vec{D}}$ of blood flow before resort to surgery ${ }^{3}$. Access to $\frac{0}{3}$ doppler and other means of flow measurement is helpful. Even so a requirement for operative treatment in the early stages of adder envenomation is a rare occurrence. However, should the patient be subjected to surgery, recovery may be prolonged. Lau and Kenna described a case of fasciotomy performed on a 12 year old adder bite victim. His recovery was prolonged, taking 20 months, the implication being that the delayed recovery was due to the operative procedure rather than the residual effects of poisoning ${ }^{22}$.

\section{Treatment Recommendations}

Reid gave good guidelines for treatment of adder음 bite $^{5}$. These include the following details. The first aid $>$ measures begin with wiping and covering the site but not? definitively dressing it. Similarly, no attempt at either washing or incising and sucking the wound should be made. These practices may actually aid the onset of 0 infection. The next stage of immediate aid is tow immobilise the affected part if necessary by splintage. 
This serves to delay the systemic distribution of the venom. Additional to this the importance of reassurance to the patient is paramount. Pain relief can be achieved by simple analgesics such as paracetamol. Seldom is any stronger pain relief necessary. Again, forceful and confident reassurance is most beneficial. Some advise that an absorption delaying bandage, rather than a tourniquet, should be applied. However, since the distinction between the two may not be apparent to the uninitiated the hazards of this device seem to outweigh its absorption delaying properties. Hence the recommendation is not to use them.

Timely resort to hospital is strongly advised. Snake bite in general, and adder bite is no exception, is an unpredictable condition. Hence, the wisdom of early referral and a full assessment by a hospital cannot be doubted. The hospital staff should reinforce any earlier reassurance and consider admission for monitoring. Reid believed that such admissions were much the wisest course because of the unpredictable nature of snake bite. Once admitted, the following need to be monitored:

1. vomiting, diarrhoea and abnormal bleeding.

2 . hourly pulse, blood pressure and respiration.

3 . white blood count, creatine phosphokinase and serum bicarbonate.

4. ECG (twice daily).

5. local swelling.

6. urinary protein and blood urea levels.

These indices will help to identify those suffering from moderate or severe envenomation. Symptomatic treatment and reassurance may be all that is required in cases of mild or even moderate poisoning. However, the definitive therapy for severe cases is the specific antivenom. This is the Zagreb preparation and should be given intravenously. Indications for treatment are persistent hypotension, leucocytosis (especially over 20 x $10^{9} /$ litre), massive swelling, ECG changes (T wave inversion and/or ST segment depression) and raised serum creatine phosphokinase levels. Reid advised that the only role for steroids was in the management of delayed serum sickness reactions ${ }^{5}$. He also counselled caution in anti-venom administration with a known allergic history. Nevertheless, anti-venom remains the only definitive treatment. Interestingly, there are no paediatric variations in dosage. Administration should be intravenously, 2 ampoules in $100 \mathrm{mls}$ of isotonic saline, using a rate of around 15 drops a minute ${ }^{5}$.

\section{Conclusions}

The adder is a species which seems to be getting more common $^{23}$. This may be a result of a succession of mild winters. At any rate any increase in the Vipera berus population is likely to lead to more envenomations. Certainly, the present low rate of bites seen in hospital represents only part of the overall picture of the condition. Many victims probably do not bother to seek medical attention. This exact number is impossible to quantify. The condition is therefore unusual. Nevertheless, it is an affliction that needs to be taken seriously because of its very unpredictability. This small series has served to illustrate some of the problems encountered by clinicians involved in these cases. By virtue of its very infrequency, few doctors have the opportunity to build up a body of experience in the management and treatment of bitten patients. Thus, therapy tends to the symptomatic rather than the definitive. The lack of resort to specific anti-venom in this series, despite severe envenoming in at least 3 cases, serves to prove this. It is to be hoped that future cases of adder bite may benefit from the experiences of the clinicians involved in this series.

\section{REFERENCES}

1. Appleby L G. British snakes. John Baker, London, 1975;11-16.

2. Parker H W and Grandison A G C. Snakes - a natural history. Cornell University Press, 1977; 90-91.

3. WARRELL D A. in Oxford Textbook of Medicine Vol $1 \mathrm{Ed}$ ○े D J Weatherell et al. OUP, Oxford; 6.35-6.42.

4. Boulenger G A. The snakes of Europe. Methuen, $\vec{N}$. London $1913 ; 230-239$.

5. Reid H A. Adder Bites in Britain. Br Med J 1976; 2: 153-6. -

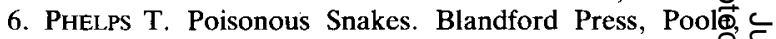
$1981 ; 1199-125$.

7. Hawley A. Adder Bites in Aldershot. $J$ R Army Mê Corps 1988; 134: 135-137.

8. APPLEBy L G. British Snakes. John Baker, London, 197א; 100-111.

9. REID H A. Animal Poisons. Manson's Tropical Disease Bailliere Tindall, London, 1982; 544-566.

10. REID H A and THEAKson R D G. The Management of Snakebite. Bull WHO 1983; 61: 855-895.

11. Gerrard $M$ and Pugh R. An adder bite with unusual $\stackrel{\mathbb{Q}}{\unrhd}$. consequences. Practitioner 1982; 226: 527-528.

12. ChaDha J $\mathrm{S}$ et al. Abnormal electrocardiogram after adder bite. Br Heart J 1968; 30: 138-140.

13. BROWN R and DEWAR H A. Heart damage following adder bite in England. Br Heart J 1965; 27: 144-146.

14. MOORE R S. Second-degree heart block associated with envenomation by Vipera berus. Arch Emerg Med 1988; 30: 116-118.

15. MORAN C J. Vipers and viper bites in the West Country. Bristol Med Chir J 1970; 85: 3-6.

16. Persson $\mathrm{H}$ and TRestedt B. A study of 136 cases of adder bite treated in Swedish hospitals during one year. Acta Med $\dot{0}$ Scand 1981; 210: 433-439.

17. Editorial. Treatment of adder bite. Lancet 1976; 2: 185186.

18. Theakston R D and ReID H A. Effectiveness of Zagreb anti-venom against envenoming by the adder Vipera berus. Lancet 1976; 2: 121-123.

19. Adder Bite in Britain. Drug Ther Bull 1966; 4: 65-66.

20. PATON B C Treatment of Snakebite. In Pye's Surgical Handicraft. Wright, Bristol, 1984; 660-671.

21. Houghton A W. Viper bites. Br Med J 1971; 2: 650.

22. LAU Y L and KenNa A P. Surgical treatment of adder bite. $J R$ Soc Med 1985; 78: 1028-1030.

23. WRIGHT W J. Adder bites. Nurs Times 1976; 74: 747-749 . 


\section{ABSTRACTS OF PUBLICATIONS}

\section{MAJOR G E VINCENTI, RAMC}

VINCENTI G E. Service families: a new perspective for the general practitioner. $B r J$ Gen Pract 1990; 40: 78-80.

Summary: "The psychological problems among the dependants of armed servicemen presenting to general practitioners are discussed, with particular emphasis on how the peculiarities of service life contribute to their aetiology and presentation. Within the UK, primary health care for service dependants is increasingly being provided by National Health Service general practitioners who have no knowledge of service life. An understanding of this minority group with its different lifestyle and subculture is important for management of these disorders".

\section{MAJOR T O JEFFERSON, RAMC, G CAROLI, G MOLINARI and A P PEIRONE}

JeFFERSON T O, CAROLI G, Molinari G and PEIRone A P. Public Health and Community Medicine in England. Rivista Italian d'Igiene 1989; 49: 226-238.

Summary: This paper reviews the evolution of Public Health and Community Medicine in England. Their origins may be traced in a vast public movement which starting from the Victorian era aimed at the improvement of the sanitary and living conditions of the overcrowded and unhealthy slums of metropolitan England. The paper traces the evolution of the functions of the Medical Officer of Health (MOH) and the history of the discipline of Public Health through the two wars until the establishment of the NHS (1948), its first (1974) and second (1985) reorganizations. The origins of the Faculty of Community Medicine (1972), the decline of the specialty and its reorganization and renaming following the Acheson Report are also reviewed.

The historical review stops short of these proposed changes introduced by Working for Patients. These will be the subject of a second review.
MAJOR T O JEFFERSON, RAMC, H BRAND, E LEVRE' and G CAROLI

JefFerson T O, Brand H, Levre' E and Caroli G. The Personal Prevention of Malaria. Rivista Italian d'Igiene 1988 ; 48: 443-450.

Summary: Malaria respresents a grave risk to the health of travellers to a country with malarial endemicity.

In order to diminish the risk of contracting the disease personal prevention measures coupled with the need to seek medical advice for any febrile episode are necessary.

The prevention of anopheline bites is based on simple personal protective measures such as the use of mosquito nets, insect repellant creams and lotions and insecticides together with chemoprophylaxis.

This has been made less efficient over the years by the $N$ appearance of $P$ Falciparum strains which are resistant $\vec{N}$ to several compounds and by the toxic effects of some antimalarial drugs.

In this paper the authors summarise three chemod prophylactic regimes currently advised in the Unite 8 Kingdom to travellers to different parts of the globe characterised by different plasmodial resistance patterns.

Chemoprophylactic regimes recommended by othe world health bodies are also mentioned.

Readers are also reminded that all patients with an appropriate travel history presenting with fever must be regarded at risk of malaria even if they have taken chemoprophylaxis. 